\title{
Circadian Misalignment Induced by Chronic Night Shift Work Promotes Endoplasmic Reticulum Stress Activation Impacting Directly on Human Metabolism
}

\author{
Rafael Ferraz-Bannitz ${ }^{1, *}{ }^{\mathbb{D}}$, Rebeca A. Beraldo ${ }^{1}$, Priscila Oliveira Coelho ${ }^{2}$, Ayrton C. Moreira ${ }^{1}$, \\ Margaret Castro ${ }^{1}\left[\right.$ and Maria Cristina Foss-Freitas ${ }^{1}[\mathbb{C}$
}

1 Division of Endocrinology and Metabolism, Department of Internal Medicine, Ribeirao Preto Medical School Avenida Bandeirantes, 3900—Vila Monte Alegre, 14049-900 Ribeirao Preto/SP, Brazil; rebecaberaldo@yahoo.com.br (R.A.B.); acmoreir@fmrp.usp.br (A.C.M.); castrom@fmrp.usp.br (M.C.); crisfoss@fmrp.usp.br (M.C.F.-F.)

2 Department of Biochemistry, Ribeirao Preto Medical School, University of Sao Paulo, Avenida Bandeirantes, 3900—Vila Monte Alegre, 14049-900 Ribeirao Preto/SP, Brazil; priscila_coelho6@hotmail.com

* Correspondence: email ferrazrafael@usp.br; Tel.: +55-1636022467

check for updates

Citation: Ferraz-Bannitz, R.; Beraldo, R.A.; Coelho, P.O.; Moreira, A.C.; Castro, M.; Foss-Freitas, M.C. Circadian Misalignment Induced by Chronic Night Shift Work Promotes Endoplasmic Reticulum Stress Activation Impacting Directly on Human Metabolism. Biology 2021, 10, 197. https://doi.org/10.3390/ biology10030197

Academic Editor: Eléonore Maury Received: 22 December 2020

Accepted: 25 January 2021

Published: 5 March 2021

Publisher's Note: MDPI stays neutra with regard to jurisdictional claims in published maps and institutional affiliations.

Copyright: (c) 2021 by the authors. Licensee MDPI, Basel, Switzerland This article is an open access article distributed under the terms and conditions of the Creative Commons Attribution (CC BY) license (https:// creativecommons.org/licenses/by/ $4.0 /)$.
Simple Summary: The demands of modern society have made shift work a necessity. Night work is associated with an increased risk of metabolic problems such as obesity and diabetes, which is mainly due to the misalignment of circadian rhythms that play a crucial role in many biological processes. This study performed clinical, anthropometric, and molecular analyses on 40 hospital workers who work day or night. We demonstrated that night workers had increased glucose levels, triglycerides, waist circumference, and blood pressure compared to day workers. Surprisingly, we report that night workers have significant changes in the expression of circadian clock genes and an up-regulation of genes related to endoplasmic reticulum stress (ERS). These findings provide new insights into the effects of night shift work on the expression of circadian cycle genes and ERS activation, leading to metabolic stress and the development of metabolic diseases associated with night work.

Abstract: Night work has become necessary in our modern society. However, sleep deprivation induces a circadian misalignment that effectively contributes to the development of diseases associated with metabolic syndrome, such as obesity and diabetes. Here, we evaluated the pattern of circadian clock genes and endoplasmic reticulum stress (ERS) genes in addition to metabolic and anthropometric measures in subjects that work during a nocturnal period compared with day workers. We study 20 night workers (NW) and 20 day workers (DW) submitted to a work schedule of $12 \mathrm{~h}$ of work for $36 \mathrm{~h}$ of rest for at least 5 years in a hospital. The present report shows that NW have increased fasting blood glucose, glycated hemoglobin (HbA1c), triglycerides, and low-density lipoprotein (LDL)-cholesterol levels, and lower high-density lipoprotein (HDL)-cholesterol levels compared to DW. In addition, we observed that waist circumference (WC), waist-hip ratio (WHR), and systemic blood pressure are also increased in NW. Interestingly, gene expression analysis showed changes in CLOCK gene expression in peripheral blood mononuclear cells (PBMC) samples of NW compared to the DW, evidencing a peripheral circadian misalignment. This metabolic adaptation was accompanied by the up-regulation of many genes of ERS in NW. These findings support the hypothesis that night shift work results in disturbed glycemic and lipid control and affects the circadian cycle through the deregulation of peripheral CLOCK genes, which is possibly due to the activation of ERS. Thus, night work induces important metabolic changes that increase the risk of developing metabolic syndrome.

Keywords: endoplasmic reticulum stress; CLOCK genes; night shift; circadian rhythm; metabolic syndrome 


\section{Introduction}

Sleep deprivation in humans is associated with the prevalence of metabolic syndrome [1-4] and increased risk of mortality [5]. Healthy individuals are those who present the temporal relations between their organism and the external environment in synchrony with their circadian cycles [6]. In this way, the expression of biological rhythms happens through the interaction of endogenous and exogenous factors. Biological rhythms can modulate many physiological processes in mammals; also, several genes are under the influence of circadian control in different tissues $[7,8]$. The act of working is intrinsic to humans; however, night work has become indispensable to the globalized economy, especially in health sectors such as hospitals. Many shift workers, especially night workers, have unhealthy eating habits and sedentary lifestyle [9], further aggravating metabolic changes. The reduction of the sleep period is directly associated with the increase of the body mass index (BMI) and food consumption in a way that is dependent on the alterations of the CLOCK genes expression [10,11]. In addition to changing habits, sleep deprivation affects daily rhythms, which are controlled by self-regulating biological oscillators. The molecular components present in the circadian cycle pathway are mainly PER 1 and $C R Y 1$ being negative regulators and CLOCK and BMAL1 as positive regulators [12-15].

It is known that endoplasmic reticulum stress (ERS) activation is a strong molecular link between obesity, lipodystrophy, functional insulin damage, and the development of type 2 diabetes mellitus $[16,17]$. The endoplasmic reticulum (E.R.) is an organelle formed by a membranous network located in the cellular cytoplasm and responsible for the synthesis and processing of secretory and membrane proteins. The pancreatic E.R. kinase (EIF2AK3) is a transmembrane protein kinase of the E.R. that phosphorylates Eukaryotic Initiation Factor $2 \alpha$ (eIF2 $\alpha$ ) in response to the ERS signal. Therefore, the phosphorylation of EIF2AK3 and eIF $2 \alpha$ is the main sign of the presence of ERS $[18,19]$. In this case, when the ERS is active by EIF2AK3, this signal is directed to activating Activator Transcription Factor 4 (ATF4), resulting in the reduction of protein synthesis and avoiding the accumulation of new malformed proteins. Furthermore, the 78-kD glucose-regulated/binding immunoglobulin protein (GRP78) is an E.R. chaperone whose gene expression is increased with ERS [20]. Nevertheless, it is not clear that metabolic changes associated with reduced sleep time result only from changes in macronutrients or energy intake.

Our hypothesis in this study is that night shift work induces important metabolic disorders such as increased levels of fasting glucose, Hb1Ac, triglycerides, and LDL, contributing to the development of the metabolic syndrome. Furthermore, we identify that night shift work affects peripheral circadian clock genes and induces the activation of ERS in night shift workers compared to day workers.

\section{Materials and Methods}

\subsection{Participants and Study Design}

Peripheral blood mononuclear cells (PBMC), serum, and plasma were obtained from 40 subjects, 20 day workers ( 10 men and 10 women) and 20 night workers (10 men and 10 women) in the intensive care unit (I.C.U.) of a large hospital in Ribeirao Preto, São Paulo, Brazil. We selected workers with no history of chronic diseases. All individuals had a Bachelor's degree, including physicians, nurses, and biomedical staff. The minimum time for individuals working at night was 5 years, while the minimum time for individuals working in the daytime period was 6 years. The working time was $12 \mathrm{~h}$, being day workers from $0700 \mathrm{~h}$ until $1900 \mathrm{~h}$ and night workers from $1900 \mathrm{~h}$ until $0700 \mathrm{~h}$. Blood samples were collected in an 8-h fasting state at $0700 \mathrm{~h}$ and $1900 \mathrm{~h}$ on the same day of work. Blood samples from daytime workers were collected at the beginning $(0700 \mathrm{~h})$ and at the end $(1900 \mathrm{~h})$ of the workday. Night workers' blood samples were collected at the beginning $(1900 \mathrm{~h})$ and end $(0700 \mathrm{~h})$ of the workday. The local Ethics Committee approved the study's protocol (Trial Registration: C.A.A.E., 82573317.3.0000.5440. Registered 07 May 2018, http:/ / plataformabrasil.saude.gov.br/visao/publico/indexPublico.jsf) and informed written consent was obtained from all patients. 
Data on usual sleep duration during the week and working day in hours were obtained from the participants using a questionnaire.

\subsection{Biochemical Analysis}

A blood sample was collected at $0700 \mathrm{~h}$ after an overnight fast of $8 \mathrm{~h}$. Plasma glucose levels and $\mathrm{Hb} 1 \mathrm{Ac}$ were measured using COBAS INTEGRA 400 plus (Roche ${ }^{\circledR}$, Indianapolis, IN, USA). Cortisol levels were measured using a radioimmunoassay by Tri-carb $2100 \mathrm{tr}$ Liquid Scintillation Analyzer (Packard ${ }^{\circledR}$, Conroe, TX, USA). Serum samples for fasting lipids were analyzed, and for the present study, serum levels of total cholesterol, LDL, HDL, and triglycerides were measured as well using COBAS INTEGRA 400 plus (Roche ${ }^{\circledR}$, Indianapolis, IN, USA).

\subsection{Anthropometric Indicators and Body Composition}

Body weight $(\mathrm{kg})$ was measured with an electronic Filizola scale of platform type with a maximum capacity of $300 \mathrm{~kg}$ and precision of $0.1 \mathrm{~kg}$. Height was measured with a stadiometer with $0.1 \mathrm{~cm}$ precision. BMI was calculated as weight $(\mathrm{kg})$ divided by height (m) squared.

The circumferences were performed using a metal measuring tape, Sanny, accurate to $0.1 \mathrm{~cm}$ and a maximum length of $2 \mathrm{~m}$.

Waist circumference (WC) was performed midway between the inferior margin of the last rib and the crest of the ilium in a horizontal plane.

The body fat percentage was obtained using a bioelectrical impedance analyzer (B.I.A.) (Biodynamics ${ }^{\circledR} 450$ model).

\subsection{R.N.A. Extract and Gene Expression Analysis}

Cells were isolated using Ficoll-Hypaque (Sigma ${ }^{\circledR}$, St. Louis, MO, USA). Total R.N.A. was extracted using Trizol reagent (Life Technologies ${ }^{\circledR}$, Carlsbad, CA, USA), following the manufacturer's instructions and confirmed to be free of proteins or phenol using U.V. spectrophotometry. The cDNA synthesis was conducted using the iScript cDNA Synthesis Kit (Bio-Rad ${ }^{\circledR}$, Hercules, CA, USA) using $1 \mu \mathrm{g}$ of total R.N.A. To assess gene expression of genes related to the circadian cycle (CLOCK genes) and endoplasmic reticulum stress (ERS), we used blood samples (PBMC) collected at $0700 \mathrm{~h}$ and $1900 \mathrm{~h}$. The gene expression was normalized to GAPDH expression and data are presented as fold change over housekeeping gene.

\subsection{RT-qPCR}

Then, the gene expression rate was evaluated by quantitative real-time PCR (qPCR). Each reaction mixture containing $250 \mathrm{nM}$ of each primer (sense and antisense), $25 \mathrm{ng}$ of cDNA, and SsoFast EvaGreen Supermix (Bio-Rad ${ }^{\circledR}$ ) in a final volume of $10 \mu \mathrm{L}$ was analyzed in a CFX96 Touch ${ }^{\mathrm{TM}}$ Real-Time PCR Detection System (Bio-Rad ${ }^{\circledR}$ ) under the following amplification conditions: $50{ }^{\circ} \mathrm{C}-2 \mathrm{~min}, 95^{\circ} \mathrm{C}-10 \mathrm{~min}, 40$ cycles of $95{ }^{\circ} \mathrm{C}-15 \mathrm{~s}$, $60{ }^{\circ} \mathrm{C}-20 \mathrm{~s}$, and $72{ }^{\circ} \mathrm{C}-30 \mathrm{~s}$ and data were analyzed with the $2^{-\Delta \Delta \mathrm{CT}}$ method. The primers sequence for the genes of interest and a housekeeping gene (GAPDH) as the endogenous control used in our experiments are shown in Supplementary Table S1.

\subsection{Statistical Analysis}

Results are expressed as the mean \pm standard deviation. We used the Student $t$-test to compare day shift vs. night shift or one-way repeated measures ANOVA as appropriate. We computed the CV (coefficient of variation, the standard deviation divided by the mean) to demonstrate the variability of cortisol levels between groups. We used the Graphpad Prism $^{\circledR} 6.5$ (Mac) of statistical tools to analyze and test the metabolic and gene expression data. Statistical significance was considered when $p<0.05$. 


\section{Results}

Demographic information for the cohort is provided in Table 1. We selected 20 individuals working during the day (DW) $(10 \mathrm{~F}, 10 \mathrm{M}$; mean age $38 \pm 6.8$; body weight $70.1 \pm 12.4$; height $1.64 \pm 0.07)$ and 20 individuals working at night (NW) $(10 \mathrm{~F}, 10 \mathrm{M}$; mean age $40 \pm 4.9$; body weight $77.3 \pm 10.0$; height $1.72 \pm 0.08$ ). The groups did not differ significantly by age $(p=0.1858)$, gender $(p=0.9999)$, body weight $(p=0.0511)$; however, the NW group was taller than the DW group ( $p=0.0041)$ (Table 1). Sleep time analyses revealed that NW group participants slept more than the DW group on working days $(9.1 \mathrm{~h} \pm 0.6 \mathrm{vs}$. $8.1 \mathrm{~h} \pm 0.5,(p=0.0001)$, Table 1). However, on free days, participants in the NW group had lower sleep time as compared with DW $(8.2 \mathrm{~h} \pm 0.4 \mathrm{vs} .8 .5 \mathrm{~h} \pm 0.5,(p=0.0210)$, Table 1$)$.

Table 1. Baseline characteristics of the subjects.

\begin{tabular}{ccc}
\hline Characteristics & Day Workers $(\boldsymbol{n = 2 0 )}$ & Night Workers $(\boldsymbol{n}=\mathbf{2 0})$ \\
\hline Age, $\mathrm{y}$ & $38(6.8)$ & $40(4.9)$ \\
Sex, \% male & $10(50 \%)$ & $10(50 \%)$ \\
Weight, $\mathrm{kg}$ & $70.1(12.4)$ & $77.3(10.0)$ \\
Height, $\mathrm{m}$ & $1.64(0.07)$ & $1.72(0.08)$ \\
Sleep time work day, $\mathrm{h}$ & $8.1(0.5)$ & $9.1(0.6)$ \\
Sleep time free day, $\mathrm{h}$ & $8.5(0.5)$ & $8.2(0.4)$ \\
\hline
\end{tabular}

Data are presented as means (standard deviation) or percentages. Abbreviations: BMI, body mass index.

\subsection{Metabolic Parameters and Anthropometric Measures}

Biochemical data are shown in Figure 1. Fasting blood glucose and glycated hemoglobin $(\mathrm{HbA} 1 \mathrm{c})$ was $14 \%(p=0.0024)$ and $14.6 \%(p<0.0001)$ higher, respectively, in NW in comparison to DW (Figure 1a,b). Evaluating the participant's lipid profile shows no differences in the total cholesterol concentration $(p=0.2153)$ (Figure 1c). Nevertheless, the triglyceride levels of the NW group were $45.7 \%(p=0.0359)$ higher compared to the DW group (Figure 1d). Plasma HDL cholesterol was significantly decreased, $17.3 \%(p=0.0456)$ in the NW group (Figure 1e). LDL cholesterol levels were $25.8 \%(p<0.0001)$ increased in the NW group compared to DW (Figure 1f). There was no difference in C Reactive Protein (C.R.P.) $(p=0.9099)$ between the groups (Figure 1g). The serum cortisol concentration was significantly higher in both groups at $0700 \mathrm{~h}$ (DW: $0700 \mathrm{~h}$ vs. $1900 \mathrm{~h}(p=0.0395)$; NW: $0700 \mathrm{~h}$ vs. $1900 \mathrm{~h}(p=0.0001)$ ), comparing samples collected at $0700 \mathrm{~h}$ vs. $1900 \mathrm{~h}$. However, we observed greater variability in cortisol among the NW group both times (coefficient of variation of NW 68.1\% vs. DW 40.6\%) and $1900 \mathrm{~h}$ (CV NW 90.2\% vs. DW 60.6\%) (Figure 1h).

The blood pressure assessment showed that NW has an increase in systolic and diastolic pressure compared to DW $(4.6 \%(p=0.0496)$ and $9.7 \%(p=0.0172)$, respectively) (Figure 2a). The body mass index (BMI) did not differ between groups ( $p=0.7801$ ) (Figure 2b). However, the waist circumference was significantly increased in the NW group by $9.8 \%(p=0.0010)$ (Figure $2 \mathrm{c})$. When analyzing the waist-hip ratio (WHR), we noticed an increase of $4.6 \%(p=0.0153)$ in the NW group compared to the DW group (Figure $2 \mathrm{~d}$ ). Lastly, there was no difference in the total fat mass between NW and DW ( $p=0.0887)$ (Figure 2e). No significant differences were found between genders.

Moreover, the correlation analyses between body weight and plasma metabolites concentration showed a significant negative correlation between body weight and triglycerides levels in the NW group $(\mathrm{r}=-0.51 ; p=0.0201)$ (Supplementary Table S2). 

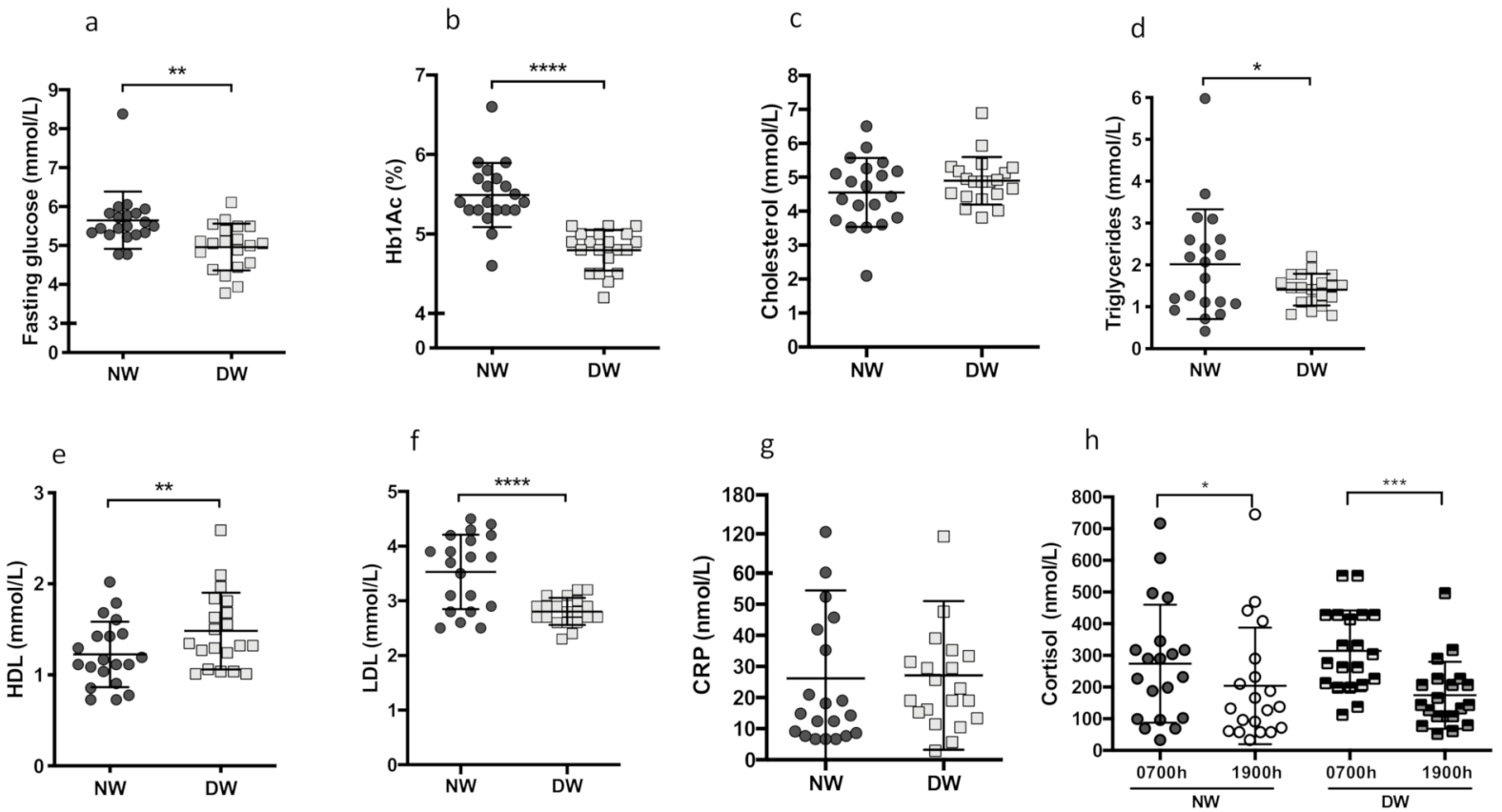

Figure 1. Metabolic changes between day and night workers. Twenty day hospital workers and twenty night hospital workers were evaluated for their metabolic parameters. (a) Fasting glucose levels $(p=0.0024),(\mathbf{b}) \mathrm{Hb} 1 \mathrm{Ac}(p<0.0001)$, (c) Cholesterol $(p=0.2153)$, (d) Triglycerides $(p=0.0359)$, (e) HDL-cholesterol $(p=0.0456)$, (f) LDL-cholesterol $(p<0.0001)$, (g) C Reactive Protein $(p=0.9099)$. Cortisol level was determined in two different blood collections at the beginning of work and another at the end of work. (h) Cortisol level, night worker $0700 \mathrm{~h}$ vs. $1900 \mathrm{~h}$ ( $p=0.0395)$, day worker $0700 \mathrm{~h}$ vs. $1900 \mathrm{~h}$ $(p=0.0001)$. Data are presented as dot plot with mean. Unpaired, one-tailed $t$-test was performed in figures a-g. One-way ANOVA followed by Tukey's post hoc test, was performed in figure h. ${ }^{*} p<0.05 ;{ }^{* *} p<0.01 ;{ }^{* * *} p=0.001 ;{ }^{* * *} p<0.0001$.

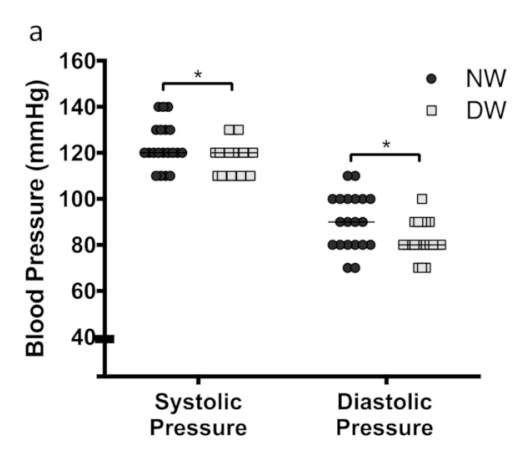

d

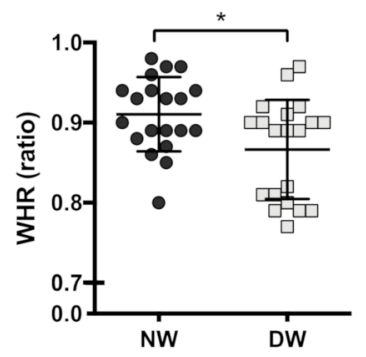

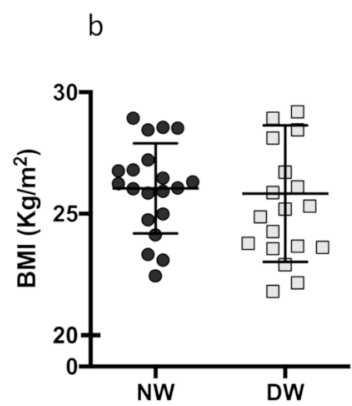

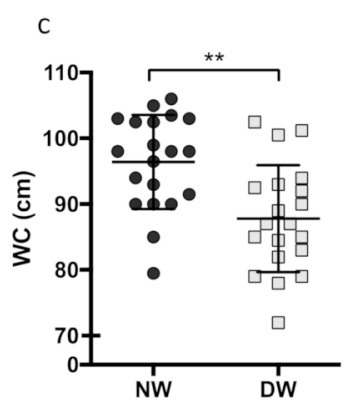

Figure 2. Blood pressure analysis and anthropometric parameters at day and night workers. (a) The blood pressure of day and night workers was verified after $20 \mathrm{~min}$ of total rest. Systolic pressure $(p=0.0496)$, Diastolic pressure $(p=0.0172)$, (b) BMI assessment $(p=0.7801)$, (c) Measurement of waist circumference $(p=0.0010)$, (d) Waist-hip ratio $(p=0.0153)$, (e) Quantification of fat mass $(p=0.0887)$. Data are presented as box plot or dot plot with mean. Unpaired, one-tailed $t$-test. ${ }^{*} p<0.05,{ }^{* *} p<0.01$. ( $n=20$ per group). 


\subsection{CLOCK Genes and the Circadian Rhythm}

The study of the mRNA expression of clock genes from PBMC samples collected at $0700 \mathrm{~h}$ and $1900 \mathrm{~h}$ indicated that in the DW group, BMAL1 expression presented a robust reduction at $1900 \mathrm{~h}(p<0.0001)$ but no change in CLOCK expression $(p=0.3980)$ (Figure 3a). However, the expression of $C R Y 1$ and PER1 showed an increase at $1900 \mathrm{~h}$ compared to $0700 \mathrm{~h}(p<0.0001 ; p=0.0330$ respectively) (Figure 3a). In the NW group, CLOCK expression did not differ between $0700 \mathrm{~h}$ and $1900 \mathrm{~h}(p=0.1465)$ (Figure 3b). In contrast, the expression of BMAL1 was significantly higher $(p<0.0001)$ and $C R Y 1$ was significantly lower $(p=0.0043)$ at $1900 \mathrm{~h}$ compared with $0700 \mathrm{~h}$ (Figure $3 \mathrm{~b}$ ). Here, we observe an interesting inversion of gene expression patterns between DW and NW groups ( $0700 \mathrm{~h}$ vs. $1900 \mathrm{~h})$. Finally, the PER1 expression was increased at $1900 \mathrm{~h}(p=0.0001)$ (Figure 3b).

Given that one of the aims of this study is to compare CLOCK genes' expression between DW and NW, we seek to understand the genetic patterns through samples taken at $0700 \mathrm{~h}$ and $1900 \mathrm{~h}$ separately. We found that CLOCK expression at $0700 \mathrm{~h}$ was increased in NW compared to DW $(p<0.0001)$ (Figure 4a). BMAL1 showed no differences between groups ( $p=0.7698$ ) (Figure 4a). Notably, CRY1 expression was increased in NW compared to DW at $0700 \mathrm{~h}(p<0.0001)$ (Figure $4 \mathrm{a})$. PER1 expression did not differ between groups $(p=0.6278)$ (Figure 4a).

However, when we analyzed the gene expression of samples collected at $1900 \mathrm{~h}$, we noticed the maintenance of increased CLOCK expression $(p<0.0001)$, which was associated with a marked increased of BMAL1 expression $(p<0.0001)$ in NW (Figure $4 b$ ). Surprisingly, $C R Y 1$ expression was reduced in NW compared with DW $(p<0.0001)$ (Figure $4 b)$, showing a pattern of gene expression inverse to that shown in samples collected at $0700 \mathrm{~h}$. Finally, PER1 expression increased in the NW group ( $p=0.0034)$ (Figure $4 b)$.
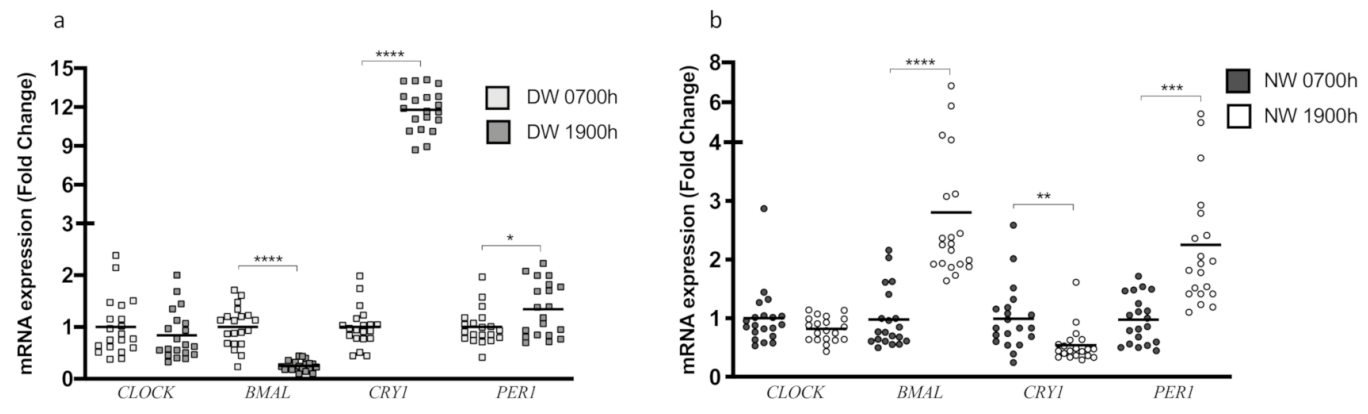

Figure 3. Determination of the gene expression of clock genes in peripheral blood mononuclear cells (PBMC) samples of day and night workers at different times. Gene expression was evaluated by RT-qPCR ( $n=20$ per group). (a) Gene expression of the clock genes of day workers at $0700 \mathrm{~h}$ and $1900 \mathrm{~h}$. (b) Gene expression of the clock genes of night workers at $0700 \mathrm{~h}$ and $1900 \mathrm{~h}$. Data are presented as dot plot with mean. Unpaired, one-tailed $t$-test. Data were normalized for values at $0700 \mathrm{~h}$. ${ }^{*} p<0.05,{ }^{* *} p<0.01,{ }^{* * *} p=0.001,{ }^{* * * *} p<0.0001$.
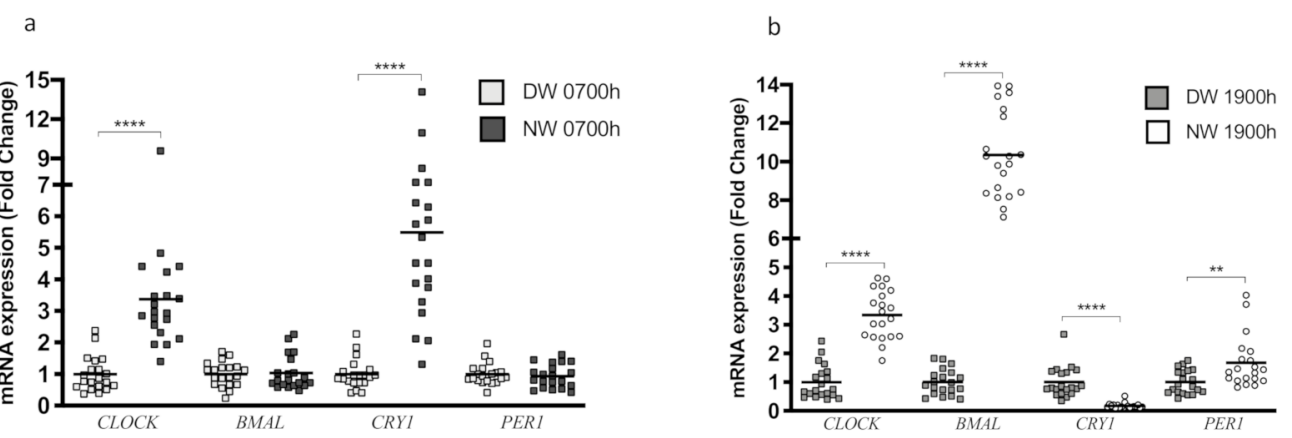

Figure 4. Determination of the gene expression of clock genes in PBMC samples of day and night workers. Gene expression was evaluated by RT-qPCR ( $n=20$ per group). (a) Gene expression of the clock genes at $0700 \mathrm{~h}$ compared DW and NW. (b) Gene expression of the clock genes at $1900 \mathrm{~h}$ compared DW and NW. Data are presented as dot plot with mean. Unpaired, one-tailed $t$-test. Data were normalized for DW. ${ }^{* *} p<0.01,{ }^{* * * *} p<0.0001$. ( $n=20$ per group). 


\subsection{Endoplasmic Reticulum Stress}

To identify the potential effect of chronic night shift work on genes related to the oxidative process and ERS, we sought to identify the gene expression patterns of PBMC samples from both groups collected at $0700 \mathrm{~h}$ and $1900 \mathrm{~h}$. Analyses of samples collected at $0700 \mathrm{~h}$ indicated that the NW group showed a robust reduction in NRF2 mRNA levels $(p=0.0015)$, which is an important regulator of the adaptive response to oxidative stress (Figure 5a). In contrast, the gene expression of EIF2AK3 ( $p<0.0001)$, ATF4 $(p<0.0001)$, ATF6 $(p<0.0001)$, and GRP78 $(p=0.0001)$ was increased in NW compared with DW, while the expression of CHOP $(p=0.1470)$ and XBP1 $(p=0.5262)$ have not been changed (Figure 5a). Consistent with the previous findings, we identified the same patterns of gene alterations in samples collected at $1900 \mathrm{~h}$. Again, NW had a decrease in NRF2 mRNA level $(p<0.0001)$; however, EIF2AK3 $(p<0.0001), \operatorname{ATF} 4(p<0.0001), A T F 6(p<0.0001)$, and GRP78 $(p=0.0001)$ mRNA levels were increased in NW compared with DW (Figure 5b). Lastly, CHOP $(p=0.8754)$ and XBP1 $(p=0.8771)$ mRNA levels remained unchanged (Figure $5 b)$. The gene expression data normalized by the DW 07:00 $\mathrm{h}$ are shown in Supplementary Figure S1.

Analysis of gender difference in ERS genes expression indicated that women in the NW group are more sensitive to the reduction of NRF2 mRNA expression than men (NW women $p=0.0014$ vs. NW men $p=0.0398)$. However, they show a greater increase in gene expression of the ATF4 (NW women $p=0.0026$ vs. NW men $p=0.0044$ ) and ATF6 (NW women $p<0.0001$ vs. NW men $p=0.0048$ ), compared to NW men (Supplementary Figure S2a,b). In addition, the samples collected at $1900 \mathrm{~h}$ showed that the effects of night work are more evident in women in the NW group, mainly on NRF2 (NW women $p<0.0001 \mathrm{vs.} \mathrm{NW} \mathrm{men}$ $p=0.2368)$; however, there are no differences between gender concerning the ERS genes (Supplementary Figure S2c,d).

We perform correlation studies to assess whether changes in ERS gene expression correlate with circadian clock gene regulation. Notably, we found significant positive correlation between gene expression of EIF2AK3 $(\mathrm{r}=0.663, p=0.002)$ and ATF4 $(\mathrm{r}=0.587$, $p=0.008$ ) with CLOCK genes at $0700 \mathrm{~h}$ in the NW group (Supplementary Table S3). In samples collected at $1900 \mathrm{~h}$, we noticed a strong positive correlation between EIF2AK3 and CLOCK $(\mathrm{r}=0.724, p<0.001)$ (Supplementary Table S3). This result supports the causality between the circadian clock genes and the alterations of ERS genes in individuals who work the night shift.

a

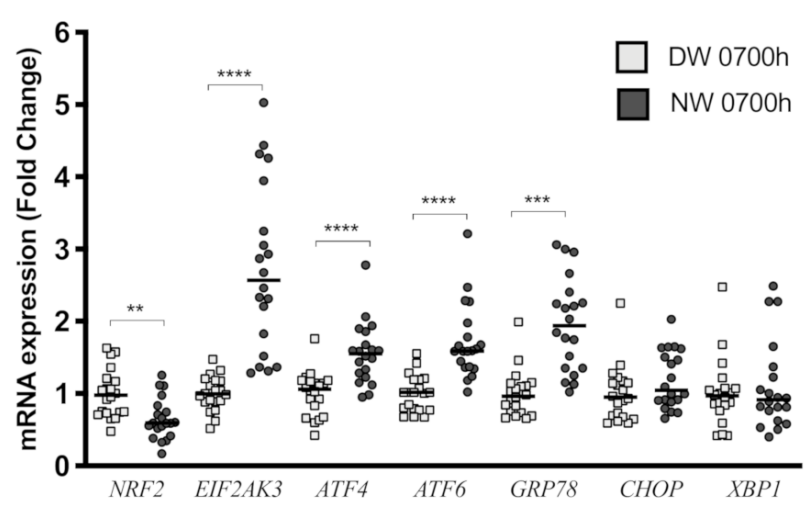

$b$

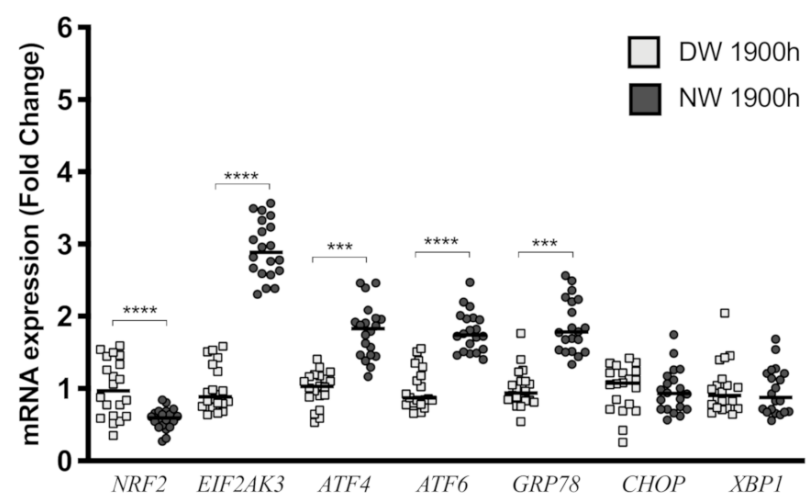

Figure 5. Determination of the expression of genes related to endoplasmic reticulum stress in PBMC samples of day and night workers at $0700 \mathrm{~h}$ and $1900 \mathrm{~h}$. (a) Graph representing diurnal variations in gene expression of genes related to endoplasmic reticulum stress (ERS). The data were normalized by day workers (DW) $0700 \mathrm{~h}$. (b) Graph representing the nocturnal variations of gene expression of genes related to ERS. The data were normalized by DW 1900 h. Gene expression was evaluated by RT-qPCR ( $n=20$ per group). Data are presented as dot plot with mean. Unpaired, one-tailed $t$-test. ${ }^{* *} p<0.01,{ }^{* * *} p=0.001,{ }^{* * * *} p<0.0001$. 


\section{Discussion}

In this study, we found that chronic night work in hospital workers directly affects metabolism and increases the risk of developing metabolic syndrome in individuals who work the night shift. Sleep pattern changes promoted by night work result in circadian cycle misalignment and ERS activation. The general characteristics of the group of workers evaluated in this study, as shown in Table 1, added to the fact that they were in the same work environment for at least 5 years, performing specific and coordinated functions, which enabled demonstrating these conclusions. Even for participants in the NW group who reported that they sleep more hours on working days than the DW group, physiological and molecular changes were found that attest to the deleterious effects of night shift work.

Poor diet, stress, and physical inactivity are the main factors contributing to the development of obesity, T2D, and cardiovascular disease, which are some of the main threats to human health [16]. Here, we found that several metabolites are elevated in individuals who work at night compared to DW, such as fasting glucose and HbA1c. Evidence linking the circadian cycle uncontrolled to diabetes shows that shift workers are at a higher risk of developing type 2 diabetes [21,22]. In addition, some studies showed that the relative risk of presenting diabetes is higher in individuals who worked consecutive night shifts compared to individuals who occupy jobs with traditional schedules [23]. Sleep deprivation or even poor sleep quality are risk factors for the appearance or exacerbation of insulin resistance and may affect appetite and adiposity [24,25]. Studies have reported that sleep continence can affect cognitive and physical performance, impairing metabolic functions, such as altered rhythm of circadian melatonin and affecting growth hormone production and being associated with the development of metabolic syndrome, hypertension, and inflammatory process $[25,26]$. We did not objectively evaluate the sleep period of the participants, but they reported that during the day, it was usually more fragmented (data not shown), which did affect the NW directly.

In this study, we found that the lipid profile of night workers is increased. Triglycerides and LDL levels of NW are increased compared to DW, and HDL levels are lower in NW compared to DW. Some studies showed associations between night shift work and increased food intake, with a preference for carbohydrate foods and changes in lipid profiles, especially triglyceride levels [26,27]. Our findings are consistent with other studies showing that night workers have higher plasma LDL levels than day workers [28].

The anthropometric results showed that the individuals working at night had WC and WHR values increased compared to DW, even though there was no difference in BMI between the groups. These data suggest a central redistribution of body fat, which has been related to an increased risk of insulin resistance and metabolic syndrome [29]. Previous authors have shown that this issue can be explained due to frequent snacks during the work period, reduced duration or absence of sleep time, and exposure to intense white light during the night of work modulating the reduced sensitivity of the internal and external rhythms [11,30]. Although much evidence shows the great impact of the association between night work and obesity, the mechanisms responsible for the connection between these factors are still unclear [31,32].

Another important finding of this study is that NW have systemic arterial pressure, systolic and diastolic, increased compared with DW. Epidemiological studies describe that shift work has negative effects on worker health, which is possibly due to its impact on sleep-wake cycles, eating habits, thermogenesis, and blood pressure levels [33-35]. The risk of systemic arterial hypertension (S.A.H.) in individuals with reduced sleep duration is significantly increased as is the risk for obesity and diabetes. This finding is consistent with the hypothesis that both the increase in adipose tissue and insulin resistance can act as mediators in the relationship between reduced sleep time and hypertension. In this way, sleep deprivation in healthy individuals may increase the risk of hypertension and the activation of the sympathetic nervous system [36]. 
One approach to determine the endogenous circadian rhythm is to assess plasma cortisol concentration. Cortisol, the end-effector of the hypothalamic-pituitary-adrenal axis, is related to anti-inflammatory responses, gluconeogenesis, and immunosuppressors [37-39] and function as a humoral signal from the central nervous system (C.N.S.) to reset peripheral clock gene expression [40]. The C.N.S. is the main synchronizer of the human circadian rhythm and coordinates the circadian controllers in the brain and peripheral tissues through signals generated in the suprachiasmatic nucleus of the hypothalamus [33].

Interestingly, we did not observe differences in cortisol concentration between NW and DW in samples collected at $0700 \mathrm{~h}$ and $1900 \mathrm{~h}$. Cortisol levels are elevated at $0700 \mathrm{~h}$, and at $1900 \mathrm{~h}$, they were reduced in all the individuals evaluated, preserving their normal physiologic pattern of oscillation. Thus, although limited, our data suggest that there is a conservation of the central circadian pacemakers of night workers even with the chronic exposure of light during the nocturnal work period. In contrast with other studies, increased cortisol levels have been found in individuals with chronic stress, including night work and changes in eating patterns, leading to the onset of metabolic syndrome [11,30].

The misalignment of the circadian cycle promoted by night work has been considered a great contributor to weight gain and visceral obesity [41,42].

Our results suggests that peripheral circadian clocks in NW are misaligned. We identified that the peripheral CLOCK expression pattern is not altered in NW. However, when we evaluated BMAL1 gene expression comparing DW with NW, we noticed the inversion of gene expression in NW, which was possibly induced by chronic night work. Another important factor that we observed was the inversion of $C R Y 1$ expression in NW, which was reduced to $1900 \mathrm{~h}$. Furthermore, we found that the expression of PER1 in NW remained unchanged, following the same pattern as DW. These data suggest that the peripheral circadian clocks' elements most sensitive to night shift work are BMAL1 and CRY1. Our data agree with a study that showed that nurses and midwives with CRY1 alterations were higher in the night shift group than day workers [43].

Circadian misalignment of NW may correlate directly with metabolic disturbances observed in night workers' clinical data compared to day workers. Skene et al. showed the link between prolonged work shift exposure and the spectrum of metabolic disturbances due to the deregulation of peripheral oscillators [44]. Another study demonstrated the importance of BMAL1 in coordinating insulin secretion with the sleep-wake cycle and how BMAL1 ablation can trigger the onset of diabetes mellitus [45].

Investigating the samples collected at $0700 \mathrm{~h}$, we noticed a different CLOCK and CRY1 expression pattern, and those two genes are increased in NW compared to DW. We also observed alterations in the samples collected at $1900 \mathrm{~h}$, where we showed that the CLOCK and BMAL1 genes remain high in NW; however, we see that CRY1 gene expression is reduced in NW compared to DW. The circadian clock is formed by feedback cycles with positive and negative components. Thus, CLOCK and BMAL1 are the positive components that are increased by day, while PER1 and CRY1 are negative components of the feedback action that are increased at night $[6,46-48]$. Here, we observe the deregulation of peripheral sensors in night workers, mainly in the expression of CLOCK and BMAL1 that remain elevated even at night, which is possibly due to the chronic stimulation of artificial light from the night work environment.

Interestingly, we report a down-regulation of NRF2 mRNA expression in NW compared to DW NRF2, which is an important oxidative stress regulator in many cell types [49]. This is the first study demonstrating that night work correlates with NRF2 mRNA expression in peripheral blood samples from NW. Our findings suggest that night shift work can alter the physiological response to oxidative stress. However, further studies should be carried out to validate this hypothesis.

One of the main results of this study is the discovery of ERS activation in NW. Clinical studies showed that ERS has a major impact on metabolic syndromes, including obesity, diabetes, and myocardial dysfunction [50]. In vivo and in vitro recent studies have reported the important role of ATF4 in the circadian regulation, showing that the activation of ER 
stress is able to inhibit the transcription of the circadian clock and of the clock-controlled genes through an ATF4-dependent mechanism [51,52]. We identify that gene expression of EIF2AK3, ATF4, ATF6, and GRP78, which are key elements of ERS activation, are upregulated in NW. Our findings are in agreement with a study showing that ER stress activation impairs the expression of the circadian clock mainly by an ATF4-dependent mechanism [52]; in addition, an animal study has shown that chronic sleep fragmentation promotes increased food intake and body weight mainly mediated by the activation of ERS [53].

Thus, our data show that night shift work can decrease the gene expression of an important marker of resistance to oxidative stress, which is a relevant factor associated with the aging process [54]. In addition, NW presented an ERS activation, which several studies have demonstrated is related to an increased risk of developing metabolic syndrome [16]. Interesting study by Wible et al. demonstrated that the loss of NRF2 function in some types of cells such as fibroblasts and hepatocytes was able to change circadian rhythms in addition to significantly reducing the duration of the cell circadian period, demonstrating in a way that NRF2 is required for normal circadian timing [55]. This study reinforces our hypothesis that night work misaligns the circadian cycle by several metabolic pathways; however, more complete future studies must be performed to prove our hypothesis. Our findings show that women who work at night shift are more sensitive to changes in ERS gene expression than men. However, more in-depth studies may shed light on the underlying mechanisms of this difference between genders mainly because in this study, we did not address gender-specific confusions such as menstrual period, use of contraceptives, and hormonal variations.

Additionally, we also reported a strong correlation between the circadian clock genes and the increase of ERS gene expression in the NW group. Our findings are consistent and support the causality between changes in gene expression of circadian clock genes, ERS, and metabolic disorders.

\section{Conclusions}

In conclusion, our findings open new perspectives for the understanding of mechanisms of how night shift work increases the risk of developing metabolic syndrome, as well as obesity, insulin resistance, and dyslipidemia. In this study, we provide evidence that night workers have significant changes in the expression of peripheral circadian clock genes and activation of ERS-related genes. Our findings add important information to understanding the deleterious effects of night shift work and open a new perspective for working policies with well-designed strategies to reduce stress in the work environment and minimize the metabolic problems arising from night shift work.

Supplementary Materials: The following are available online at https:/ / www.mdpi.com/2079-7 737/10/3/197/s1, Figure S1: Determination of the expression of genes related to Endoplasmic reticulum stress in P.B.M.C. samples of day and night workers at $0700 \mathrm{~h}$ and $1900 \mathrm{~h}$ normalized by DW at 07:00 h, Figure S2: Gene expression related to Endoplasmic Reticulum Stress genes in P.B.M.C. samples of day and night workers collected at $0700 \mathrm{~h}$ and $1900 \mathrm{~h}$, Table S1: Sequences of the oligonucleotides. Oligonucleotides used for the analysis of expression in PBMC samples, Table S2: Correlation between body weight and blood metabolites, Table S3: Correlation between ERS genes and CLOCK genes at $0700 \mathrm{~h}$ and $1900 \mathrm{~h}$.

Author Contributions: R.F.-B. prepared material, designed and performed all the experiments, analyzed data and wrote the manuscript. R.A.B. performed the anthropometric analyzes. P.O.C. performed RNA extraction. A.C.M. and M.C. analyzed and discussed the CLOCK gene expression. M.C.F.-F. supervised the study and revised the manuscript. All authors have read and agreed to the published version of the manuscript.

Funding: This work was supported by Fundação de Apoio ao Ensino Pesquisa e Assistencia (FAEPA) and the Fundação de Amparo à Pesquisa do Estado de São Paulo-FAPESP (2015/12133-0). 
Institutional Review Board Statement: The study was conducted according to the guidelines of the Declaration of Helsinki, and approved by the Ethics Committee of Plataforma Brasil (protocol code C.A.A.E., 82573317.3.0000.5440, registered 07 May 2018).

Informed Consent Statement: Informed consent was obtained from all subjects involved in the study.

Data Availability Statement: The data presented in this study are available on request from the corresponding author.

Acknowledgments: We thank all the employees of the São Lucas hospital of Ribeirao Preto for the attention and donation of the biological samples for the accomplishment of this study. Maria Aparecida Nunes Ferreira for technical support.

Conflicts of Interest: The authors declare no conflict of interest.

\begin{abstract}
Abbreviations
ERS, Endoplasmic Reticulum Stress; NW, night workers; DW, day workers; B.P., blood pressure; BMI, body mass index; WC, waist circumference; W.H.P., waist-hip ratio; E.R., endoplasmic reticulum; EIF2AK3, pancreatic E.R. kinase; eIF2 $\alpha$, Eukaryotic Initiation Factor $2 \alpha$; ATF6, Activator Transcription Factor 6; GRP78, 78-kD glucose-regulated/binding immunoglobulin protein; P.B.M.C., Peripheral blood mononuclear cells; HDL, high-density lipoprotein; C.R.P., C-Reactive Protein.
\end{abstract}

\title{
References
}

1. Cappuccio, F.P.; Taggart, F.M.; Kandala, N.B.; Currie, A.; Peile, E.; Stranges, S.; Miller, M.A. Meta-analysis of short sleep duration and obesity in children and adults. Sleep 2008, 31, 619-626. [CrossRef] [PubMed]

2. Stranges, S.; Dorn, J.M.; Cappuccio, F.P.; Donahue, R.P.; Rafalson, L.B.; Hovey, K.M.; Freudenheim, J.L.; Kandala, N.B.; Miller, M.A.; Trevisan, M. A population-based study of reduced sleep duration and hypertension: The strongest association may be in premenopausal women. J. Hypertens 2010, 28, 896-902. [CrossRef] [PubMed]

3. Ayas, N.T.; White, D.P.; Al-Delaimy, W.K.; Manson, J.E.; Stampfer, M.J.; Speizer, F.E.; Patel, S.; Hu, F.B. A prospective study of self-reported sleep duration and incident diabetes in women. Diabetes Care 2003, 26, 380-384. [CrossRef] [PubMed]

4. Cappuccio, F.P.; Cooper, D.; D’Elia, L.; Strazzullo, P.; Miller, M.A. Sleep duration predicts cardiovascular outcomes: A systematic review and meta-analysis of prospective studies. Eur. Heart J. 2011, 32, 1484-1492. [CrossRef] [PubMed]

5. Cappuccio, F.P.; D’Elia, L.; Strazzullo, P.; Miller, M.A. Sleep duration and all-cause mortality: A systematic review and metaanalysis of prospective studies. Sleep 2010, 33, 585-592. [CrossRef] [PubMed]

6. Gekakis, N.; Staknis, D.; Nguyen, H.B.; Davis, F.C.; Wilsbacher, L.D.; King, D.P.; Takahashi, J.S.; Weitz, C.J. Role of the CLOCK protein in the mammalian circadian mechanism. Science 1998, 280, 1564-1569. [CrossRef]

7. Panda, S.; Antoch, M.P.; Miller, B.H.; Su, A.I.; Schook, A.B.; Straume, M.; Schultz, P.G.; Kay, S.A.; Takahashi, J.S.; Hogenesch, J.B. Coordinated transcription of key pathways in the mouse by the circadian clock. Cell 2002, 109, 307-320. [CrossRef]

8. Storch, K.F.; Lipan, O.; Leykin, I.; Viswanathan, N.; Davis, F.C.; Wong, W.H.; Weitz, C.J. Extensive and divergent circadian gene expression in liver and heart. Nature 2002, 417, 78-83. [CrossRef]

9. Costa, G. Multidimensional aspects related to shiftworkers' health and well-being. Rev. Saude Publica 2004, 38, 86-91. [CrossRef]

10. Dashti, H.S.; Follis, J.L.; Smith, C.E.; Tanaka, T.; Cade, B.E.; Gottlieb, D.J.; Hruby, A.; Jacques, P.F.; Lamon-Fava, S.; Richardson, K.; et al. Habitual sleep duration is associated with BMI and macronutrient intake and may be modified by CLOCK genetic variants. Am. J. Clin. Nutr 2015, 101, 135-143. [CrossRef]

11. Ajabnoor, G.M.; Bahijri, S.; Shaik, N.A.; Borai, A.; Alamoudi, A.A.; Al-Aama, J.Y.; Chrousos, G.P. Ramadan fasting in Saudi Arabia is associated with altered expression of CLOCK, DUSP and IL-1alpha genes, as well as changes in cardiometabolic risk factors. PLoS ONE 2017, 12, e0174342. [CrossRef] [PubMed]

12. Rutter, J.; Reick, M.; McKnight, S.L. Metabolism and the control of circadian rhythms. Annu. Rev. Biochem. 2002, 71, 307-331. [CrossRef] [PubMed]

13. Honma, S.; Kawamoto, T.; Takagi, Y.; Fujimoto, K.; Sato, F.; Noshiro, M.; Kato, Y.; Honma, K. Dec1 and Dec2 are regulators of the mammalian molecular clock. Nature 2002, 419, 841-844. [CrossRef] [PubMed]

14. Lowrey, P.L.; Takahashi, J.S. Genetics of the mammalian circadian system: Photic entrainment, circadian pacemaker mechanisms, and posttranslational regulation. Annu. Rev. Genet. 2000, 34, 533-562. [CrossRef] [PubMed]

15. Roa, S.L.R.; Martinez, E.Z.; Martins, C.S.; Antonini, S.R.; De Castro, M.; Moreira, A.C. Postnatal Ontogeny of the Circadian Expression of the Adrenal Clock Genes and Corticosterone Rhythm in Male Rats. Endocrinology 2017, 158, 1339-1346. [CrossRef]

16. Ozcan, U.; Cao, Q.; Yilmaz, E.; Lee, A.H.; Iwakoshi, N.N.; Ozdelen, E.; Tuncman, G.; Gorgun, C.; Glimcher, L.H.; Hotamisligil, G.S. Endoplasmic reticulum stress links obesity, insulin action, and type 2 diabetes. Science 2004, 306, 457-461. [CrossRef] 
17. Foss-Freitas, M.C.; Ferraz, R.C.; Monteiro, L.Z.; Gomes, P.M.; Iwakura, R.; De Freitas, L.C.C.; Foss, M.C. Endoplasmic reticulum stress activation in adipose tissue induces metabolic syndrome in individuals with familial partial lipodystrophy of the Dunnigan type. Diabetol. Metab. Syndr. 2018, 10, 6. [CrossRef]

18. Shi, Y.; Taylor, S.I.; Tan, S.L.; Sonenberg, N. When translation meets metabolism: Multiple links to diabetes. Endocr. Rev. 2003, 24, 91-101. [CrossRef]

19. Shi, Y.; Taylor, S.I.; Tan, S.L.; Sonenberg, N. Identification and characterization of pancreatic eukaryotic initiation factor 2 alpha-subunit kinase, PEK, involved in translational control. Mol. Cell Biol. 1998, 18, 7499-7509. [CrossRef]

20. Harding, H.P.; Calfon, M.; Urano, F.; Novoa, I.; Ron, D. Transcriptional and translational control in the Mammalian unfolded protein response. Annu. Rev. Cell Dev. Biol. 2002, 18, 575-599. [CrossRef]

21. Pan, A.; Schernhammer, E.S.; Sun, Q.; Hu, F.B. Rotating night shift work and risk of type 2 diabetes: Two prospective cohort studies in women. PLoS Med. 2011, 8, e1001141. [CrossRef] [PubMed]

22. Kroenke, C.H.; Spiegelman, D.; Manson, J.; Schernhammer, E.S.; Colditz, G.A.; Kawachi, I. Work characteristics and incidence of type 2 diabetes in women. Am. J. Epidemiol. 2007, 165, 175-183. [CrossRef] [PubMed]

23. Morikawa, Y.; Nakagawa, H.; Miura, K.; Soyama, Y.; Ishizaki, M.; Kido, T.; Naruse, Y.; Suwazono, Y.; Nogawa, K. Shift work and the risk of diabetes mellitus among Japanese male factory workers. Scand. J. Work Environ. Health 2005, 31, 179-183. [CrossRef] [PubMed]

24. Kalsbeek, A.; La Fleur, S.; Fliers, E. Circadian control of glucose metabolism. Mol. Metab. 2014, 3, 372-383. [CrossRef]

25. Perez-Tilve, D.; Stern, J.E.; Tschop, M. The brain and the metabolic syndrome: Not a wireless connection. Endocrinology 2006, 147, 1136-1139. [CrossRef]

26. Brum, M.C.; Filho, F.F.; Schnorr, C.C.; Bottega, G.B.; Rodrigues, T.C. Shift work and its association with metabolic disorders. Diabetol. Metab. Syndr. 2015, 7, 45. [CrossRef]

27. Al-Naimi, S.; Hampton, S.M.; Richard, P.; Tzung, C.; Morgan, L.M. Postprandial metabolic profiles following meals and snacks eaten during simulated night and day shift work. Chronobiol. Int. 2004, 21, 937-947. [CrossRef]

28. Ghiasvand, M.; Heshmat, R.; Golpira, R.; Haghpanah, V.; Soleimani, A.; Shoushtarizadeh, P.; Tavangar, S.M.; Larijani, B. Shift working and risk of lipid disorders: A cross-sectional study. Lipids Health Dis. 2006, 5, 9. [CrossRef]

29. Patel, P.; Abate, N. Body fat distribution and insulin resistance. Nutrients 2013, 5, 2019-2027. [CrossRef]

30. Bahijri, S.; Borai, A.; Ajabnoor, G.; Abdul Khaliq, A.; AlQassas, I.; Al-Shehri, D.; Chrousos, G. Relative metabolic stability, but disrupted circadian cortisol secretion during the fasting month of Ramadan. PLoS ONE 2013, 8, e60917. [CrossRef]

31. Van Amelsvoort, L.G.; Schouten, E.G.; Kok, F.J. Impact of one year of shift work on cardiovascular disease risk factors. J. Occup. Environ. Med. 2004, 46, 699-706. [CrossRef] [PubMed]

32. Hannerz, H.; Albertsen, K.; Nielsen, M.L.; Tuchsen, F.; Burr, H. Occupational factors and 5-year weight change among men in a danish national cohort. Health Psychol. 2004, 23, 283-288. [CrossRef] [PubMed]

33. Garaulet, M.; Ordovas, J.M.; Madrid, J.A. The chronobiology, etiology and pathophysiology of obesity. Int. J. Obes. 2010, 34, 1667-1683. [CrossRef]

34. Van Someren, E.J.; Riemersma-Van Der Lek, R.F. Live to the rhythm, slave to the rhythm. Sleep Med. Rev. 2007, 11, 465-484. [CrossRef]

35. Knutsson, A. Health disorders of shift workers. Occup Med. 2003, 53, 103-108. [CrossRef] [PubMed]

36. Gangwisch, J.E.; Malaspina, D.; Boden-Albala, B.; Heymsfield, S.B. Inadequate sleep as a risk factor for obesity: Analyses of the NHANES I. Sleep 2005, 28, 1289-1296. [CrossRef]

37. Dijk, D.J.; Duffy, J.F.; Silva, E.J.; Shanahan, T.L.; Boivin, D.B.; Czeisler, C.A. Amplitude reduction and phase shifts of melatonin, cortisol and other circadian rhythms after a gradual advance of sleep and light exposure in humans. PLoS ONE 2012, 7, e30037. [CrossRef]

38. Korompeli, A.; Sourtzi, P.; Tzavara, C.; Velonakis, E. Rotating shift-related changes in hormone levels in intensive care unit nurses. J. Adv. Nurs. 2009, 65, 1274-1282. [CrossRef]

39. Scheer, F.A.; Hilton, M.F.; Mantzoros, C.S.; Shea, S.A. Adverse metabolic and cardiovascular consequences of circadian misalignment. Proc. Natl. Acad. Sci. USA 2009, 106, 4453-4458. [CrossRef]

40. Moreira, A.C.; Antonini, S.R.; De Castro, M. Mechanisms in Endocrinology: A sense of time of the glucocorticoid circadian clock: From the ontogeny to the diagnosis of Cushing's syndrome. Eur. J. Endocrinol. Eur. Fed. Endocr. Soc. 2018, 179, R1-R18. [CrossRef]

41. McHill, A.W.; Melanson, E.L.; Higgins, J.; Connick, E.; Moehlman, T.M.; Stothard, E.R.; Wright, K.P., Jr. Impact of circadian misalignment on energy metabolism during simulated nightshift work. Proc. Natl. Acad. Sci. USA 2014, 111, 17302-17307. [CrossRef] [PubMed]

42. Kim, S.; Lee, H.S.; Park, H.K.; Linton, J.A.; Lee, J.W.; Lee, H. Visceral adiposity and expression of clock genes in peripheral blood mononuclear cells: A pilot study. Chronobiol. Int. 2017, 34, 1057-1066. [CrossRef] [PubMed]

43. Reszka, E.; Peplonska, B.; Wieczorek, E.; Sobala, W.; Bukowska, A.; Gromadzinska, J.; Lie, J.A.; Kjuus, H.; Wasowicz, W. Rotating night shift work and polymorphism of genes important for the regulation of circadian rhythm. Scand. J. Work Environ. Health 2013, 39, 178-186. [CrossRef] [PubMed]

44. Skene, D.J.; Skornyakov, E.; Chowdhury, N.R.; Gajula, R.P.; Middleton, B.; Satterfield, B.C.; Porter, K.I.; Van Dongen, H.P.A.; Gaddameedhi, S. Separation of circadian- and behavior-driven metabolite rhythms in humans provides a window on peripheral oscillators and metabolism. Proc. Natl. Acad. Sci. USA 2018, 115, 7825-7830. [CrossRef] [PubMed] 
45. Marcheva, B.; Ramsey, K.M.; Buhr, E.D.; Kobayashi, Y.; Su, H.; Ko, C.H.; Ivanova, G.; Omura, C.; Mo, S.; Vitaterna, M.H.; et al. Disruption of the clock components CLOCK and BMAL1 leads to hypoinsulinaemia and diabetes. Nature 2010, 466, 627-631. [CrossRef] [PubMed]

46. Darlington, T.K.; Wager-Smith, K.; Ceriani, M.F.; Staknis, D.; Gekakis, N.; Steeves, T.D.; Weitz, C.J.; Takahashi, J.S.; Kay, S.A. Closing the circadian loop: CLOCK-induced transcription of its own inhibitors per and tim. Science 1998, 280, 1599-1603. [CrossRef] [PubMed]

47. Shearman, L.P.; Sriram, S.; Weaver, D.R.; Maywood, E.S.; Chaves, I.; Zheng, B.; Kume, K.; Lee, C.C.; Van der Horst, G.T.; Hastings, M.H.; et al. Interacting molecular loops in the mammalian circadian clock. Science 2000, 288, 1013-1019. [CrossRef]

48. Griffin, E.A., Jr.; Staknis, D.; Weitz, C.J. Light-independent role of CRY1 and CRY2 in the mammalian circadian clock. Science 1999, 286, 768-771. [CrossRef]

49. Schafer, M.; Werner, S. Nrf2-A regulator of keratinocyte redox signaling. Free Radic. Biol. Med. 2015, 88, 243-252. [CrossRef]

50. Ghemrawi, R.; Battaglia-Hsu, S.F.; Arnold, C. Endoplasmic Reticulum Stress in Metabolic Disorders. Cells 2018, 7, 63. [CrossRef]

51. Koyanagi, S.; Hamdan, A.M.; Horiguchi, M.; Kusunose, N.; Okamoto, A.; Matsunaga, N.; Ohdo, S. cAMP-response element (CRE)-mediated transcription by activating transcription factor-4 (ATF4) is essential for circadian expression of the Period2 gene. J. Biol. Chem. 2011, 286, 32416-32423. [CrossRef] [PubMed]

52. Gao, L.; Chen, H.; Li, C.; Xiao, Y.; Yang, D.; Zhang, M.; Zhou, D.; Liu, W.; Wang, A.; Jin, Y. ER stress activation impairs the expression of circadian clock and clock-controlled genes in NIH3T3 cells via an ATF4-dependent mechanism. Cell Signal. 2019, 57, 89-101. [CrossRef] [PubMed]

53. Hakim, F.; Wang, Y.; Carreras, A.; Hirotsu, C.; Zhang, J.; Peris, E.; Gozal, D. Chronic sleep fragmentation during the sleep period induces hypothalamic endoplasmic reticulum stress and PTP1b-mediated leptin resistance in male mice. Sleep 2015, 38, 31-40. [CrossRef] [PubMed]

54. Zhang, H.; Davies, K.J.A.; Forman, H.J. Oxidative stress response and Nrf2 signaling in aging. Free Radic. Biol. Med. 2015, 88, 314-336. [CrossRef] [PubMed]

55. Wible, R.S.; Ramanathan, C.; Sutter, C.H.; Olesen, K.M.; Kensler, T.W.; Liu, A.C.; Sutter, T.R. NRF2 regulates core and stabilizing circadian clock loops, coupling redox and timekeeping in Mus musculus. Elife 2018, 7, e31656. [CrossRef] [PubMed] 